\title{
Do Budget Deficit Crowds out Private Investment: A Case of Tanzanian Economy
}

\section{Samwel Mwigeka}

Assistant Lecturer, Ruaha Catholic University, P. O. BOX 774 Iringa, TANZANIA

E-mail for correspondence: mwigeka82@yahoo.com

Cell Phone: +255718083005

Received: Jun 03, 2015;

Accepted: Jun 22, 2015;

Published: Jul 20, 2015

Source of Support: Nil

No Conflict of Interest: Declared

\begin{abstract}
The existing high budget deficit in Tanzanian economy has created an immense concern among economic policy analysts. The study investigates whether budget deficits crowd out or crowd in private investment in Tanzania, using annual data covering the period from 1970 to 2012. Using the Johansen cointegration test suggests there is at least one cointegration vector among these variables. Under such circumstances, we employed a vector error correction model (VEC), since it offers more and better information compared to other data generation processes. The results point to a close longterm relationship between private investment, and other variables included in the study. Results suggest that budget deficits significantly crowds out private investment. These results substantiate the theoretical predictions and are also supported by previous studies. The paper recommends that government should redirect it fiscal policy that would favor the private investor by discouraging high government expenditure and maintaining a low fiscal deficit. Also, to avoid crowding out effect, capital market should be used to finance budget deficit.
\end{abstract}

Keywords: Budget Deficits, Co-integration, Private investment, VECM JEL Classifications Code: $\mathrm{H} 6$

\section{INTRODUCTION}

Tanzania is one of the world's poorest economies in terms of per capita income; however, it has achieved high growth based on gold production and tourism. The economy depends on agriculture that accounts for more than one-quarter of GDP, provides $85 \%$ of exports, and employs about $80 \%$ of the workforce. However, the economy has achieved high growth based on gold production and tourism. The recent banking reforms have helped increase private-sector growth and investment, and the government has increased spending on agriculture to $7 \%$ of its budget (Economic Survey, 2012)

Chronic government budget deficits and escalating debt have become major concerns in both developed and developing countries. An extensive theoretical and empirical literature has been developed to examine the relationship between the budget deficit and macroeconomic variables. Among others includes Premchand (1984), who asserts that financing the budget deficit by borrowing from the public implies an increase in the supply of government bonds. To improve the attractiveness of these bonds, the government offers them at a lower price, which leads to higher interest rates. The increase in interest rates discourages the issue of private bonds, private investment, and private spending. In turn, this contributes to the financial crowding out of the private sector.

One of the bones of controversy between Keynesians and Monetarists is on the effectiveness of fiscal action in stimulating economic activity. Economists have a common belief that budget deficits are harmful for the total functioning of the economy. According to Easterly and Rebelo (1993) fiscal deficits have been blamed for the variety of evils that beset developing and industrial countries. These evils include over indebtedness, high inflation and poor investment and growth performance. The driving force behind economic policymaking lies in the macroeconomic objectives which are price stability, employment, economic growth, balance of payments surplus and equity (Chowdhury and Hossain, 1998).

There is, however, quite a large gap between the modern theory of investment and the models that have been specified for developing countries. This gap is the result of a variety of causes, both analytical and pragmatic. The causes include institutional and structural factors present in most developing countries such as the absence of wellfunctioning financial markets the relatively larger role of the government in capital formation, distortions created by foreign exchange constraints, and other market 
imperfections-the assumptions underlying the standard optimizing investment models typically are not satisfied in these countries.

The rudimentary nature of capital markets in developing countries limits the financing of private investment to the use of retained profits, bank credit, and foreign borrowing. Of these, the flow of bank credit to the private sector would perhaps tend to be quantitatively the most important. An increase in real credit to the private sector will in general encourage real private investment, and rolling over bank loans can sufficiently lengthen the maturity of the debt.

Finally, it is a well-accepted proposition that in developing countries private and public investment are related although there is considerable uncertainty about whether, on balance, public sector investment raises or lowers private investment. In broad terms, public sector investment can cause crowding out if it utilizes scarce physical and financial resources that would otherwise be available to the private sector, or if it produces marketable output that competes with private.

Furthermore, the financing of public sector investmentwhether through taxes, issuance of debt, or inflation will lower the resources available to the private sector and thus depress private investment activity. Public investment that is related to infrastructure and the provision of public goods can also clearly be complementary to private investment. Public investment of this type enhances the expansion private investment.

\section{Private Investment Trends in Tanzania}

Tanzania has made major progress over recent years towards putting into place a general policy environment which is more favorable for private sector expansion and sustainable economic development. The country has shifted from its previous reliance on control mechanisms to a predominantly market-oriented environment, mainly with respect to investment, the external sector, monetary management and agricultural marketing arrangements. Restrictive controls have been removed. The foreign exchange system is being completely liberalized for payments and transfers for current international transactions (URT, 1996).

Progress has been made with the development of a more market-oriented financial system with the liberalization of interest rates. A substantial number of both local and foreign banks and non-banking institutions have been established in order to provide short, medium and long term loans to investors. Domestic and foreign investors are encouraged to establish development banks for venture capital and lease financing so as to match and facilitate the country's current pace with regard to investment and productivity. The tax regime is being reviewed with the view to make it more rational, simple and equitable (URT, 1996).

Consistent with ongoing reforms, the Government of the United Republic of Tanzania has redefined the role of the state to that of policy maker. However, the government recognizes that it has the role to facilitate the private sector and other economic agents by actively and effectively investing in productive and commercial activities. The Government can do this mainly through putting favourable policies in place and provision of attractive environment for domestic and foreign investment (OECD, 2013).

The National Investment Promotion Policy of 1996 opened almost all sectors to foreign and private participation. The Tanzania Investment Act of 1997 provides the backbone of the legal investment regime by making provisions that enables attractive environment conditions. It includes separate legislation for investment in mining and petroleum and also the introduction of Export Processing and Special Economic Zones (EPZs and SEZs). The 1997 Act also establishes the Tanzania Investment Centre (TIC) as a 'one-stop' office for investors. TIC provides information about the land acquisition, taxes, and investment incentives in priority sectors and spearheads investment promotion and facilitation efforts in the country (OECD, 2013).

Furthermore, the private sector itself has evolved institutional mechanisms of interactions and consultations with the government through umbrella organisation such as the National Investment Steering Committee (NISC, established in 2000 under chairmanship of the President), and the Tanzania National Business Council. TNBC was set up in 2001 as the highest consultative organ between the private sector and the government (OECD, 2013).

Nonetheless, Tanzania's current national strategies for economic reform strongly emphasize the importance of encouraging private participation in the economy. The Second National Strategy for Growth and Reduction in Poverty (NSGRP adopted 2010) or MKUKUTA II (for the mainland), provides an operational framework for achieving the MDGs and Tanzania's Development Vision 2025 which aims to transform Tanzania into a middleincome country. It calls for enhancing the role of the private sector in generating economic growth and identifies agriculture as one of the central growth drivers. Since 2011 MKUKUTA works in parallel with the National Five Year Development Plan I (FYDP 2011/12 2015/16), the first of a series of three five-year plans that will attempt to address MKUKUTA implementation challenges. A salient feature of FYDP I is scaling up the role of the private sector in economic growth, by improving the business climate as well as investing in people and infrastructure development. (Economic Survey, 2012)

A viable private sector is an important economic agent for stimulating growth. The public sector should provide at a manageable economic cost, the necessary infrastructure and an overall environment conducive to sound investment. Without this, the private sector is unlikely to make its full contribution to development. An inefficient and ineffective government, or one with policies that significantly distort private sector decision making, will 
have a negative impact on both the private and public sector (Kilindo and Moshi, 1999).

With an underdeveloped capital market, financing of private sector investment relies heavily on retained profits, bank credit, and foreign sources. Of the three, the flow of bank credit to the private sector is the most vital source of investable resources. The study by Mjema (1994), and Lipumba and Noni (1993) among others, explains the role of foreign sources in the domestic investment process in developing countries.

The essential source of private investment financing in Tanzania is bank credit. An observation of trends in credit to the private sector indicates that the share of private investment declined as the credit to this sector was restrained. For example, between 1967 and 1975 the proportion of bank credit (National Bank of Commerce) to the private sector declined from $95.4 \%$ to $11.7 \%$, leading to a fall by $83.1 \%$. Private investment and credit to the private sector moved in the same direction. Periods of a high proportion of bank credit to the private sector are mostly characterized by high levels of investment and growth of the economy. Inflation and growth were moving in opposite directions, thus underscoring that high inflation rates are detrimental to growth (Kilindo and Moshi, 1999).

\section{Budget Deficits Trends in Tanzania}

During the war with Idd Amin of Uganda in 1978/79 took a financial and social toll. It is estimated to cost about USD 500 million, this led to high budget deficit of over 10 percent in 1980's (Kilindo, 1993). Fiscal deficits started to increase sharply in the 1970s from less than 10 percent to 15.3 percent in 1981 much of this was due to sharp rise in government spending which averaged above 30 percent of GDP between 1975 and 1985.

Moreover in 1980s, most developing countries especially those of Africa started with large fiscal imbalances from fluctuations in GDP, high government spending with declining trade tax revenue because of the collapse of commodity prices during the period. These economic problems lead to increased budget deficit and public debt levels. Moreover, the two oil price shocks in the mid1970s and 1980s made the economies of the non-oil exporting countries suffer much with the rise in oil prices. Government budgeting in Tanzania has always been deficit-ridden. For example in the five-year period ending on 30th June 1995, the government budget deficit ranged from $17 \%$ to $34 \%$ of total government expenditure (IMF, 1996). The situation is actually much worse if the computation of the budget deficit excludes grants from government revenue. According to BOT (1995), grants did account on average for $21 \%$ of total government revenue (tax + non-tax + grants) over the same specified period.

Deficit spending in Tanzania has been the subject of much concern in Tanzania's current economic problems. Particularly, government spending is considered to have contributed significantly to the country's inflation and external imbalance. Accordingly, surmounting these phenomena has been seen as being very much dependent on securing a closer look at the dynamics of the components of the budget balance.

According to the central bank (Bank of Tanzania), the government has been continuously pursuing an expansionary fiscal policy with exclusion of the year's 1997, 1998 and 2000. The main culprit for the expansionary fiscal stance was increasing pressure from the public seeking to achieve faster economic growth. The government responded by expanding its expenditure on development projects and infrastructure improvements. However, when the impact of the increasing fiscal deficit responded at the end of 1996, an immediate policy shift was observed. The ensuing macroeconomic instability (high inflation rate and high-interest rates) was combated using tight fiscal discipline.

The fiscal deficit has continued to rise in 2000s while revenue does not increase significantly; both public spending and financial deficit have also continued to expand. The fiscal deficit (after grants) reached 1939624 million TZS in 2009/10 from 38757 million TZS in 2001/02 (URT, 2011) as a result of excessive expenditure due to the implementation of the objectives of the National Development Vision 2025 and reduction of poverty (NSGRP). Furthermore, expansion of fiscal deficit resulted from the impact of the global financial crisis that led to a slower growth in taxable production activities in the economy.

\section{LITERATURE REVIEW}

Theoretical Framework

Budget Deficits, Crowding in and Crowding out Effects Schools of Thought

There exist opposing theoretical links in explaining the relationship between budget deficits and private investment that include three distinct schools of thought; these are Neoclassical, Keynesian, and Ricardian equivalence. Each providing different paradigms, Bernhein (1989) provides a brief summary of the three. The Neoclassical school considers individuals are planning their consumption over their entire life cycle. It includes shifting taxes to future generations, budget deficits increase current consumption. Also, by assuming full employment of resources, the neoclassical school argues that increased consumption implies a decrease in saving. Interest rates must rise to bring equilibrium in the capital markets. Thus, the rise in interest leads to a decline in private investment.

Also, there are Keynesians who provide a counter argument to the crowd in effect by making reference to the expansionary effects of budget deficits. They argue that usually budget deficits result in an increase in domestic production, which makes private investors more optimistic about the future course of the economy resulting in them were investing more. The rise in private investment due expansionary budget deficit is known as the "crowding in" effect. It is worth noting here that the traditional Keynesian view differs from the standard neoclassical paradigm in two fundamental ways. First, it permits the possibility that 
some economic resources are unemployed. Second, it presupposes the existence of a large number of liquidity constrained individuals. The second assumption guarantees that aggregate consumption is very sensitive to changes in disposable income.

Many traditional Keynesians argue that deficits need not crowd out private investment. Eisner (1989) is an example of this group, who suggests that increased aggregate demand enhances the profitability of private investments and leads to a higher level of investment at any given rate of interest. Hence, deficits may stimulate aggregate saving and investment, despite the fact that they raise interest rates. He concludes that "The evidence is that, deficits have not been crowding out investment but there has been crowding in".

\section{Empirical Literature}

The study by Blejar and Khan (1984) in Ivory Coast, Thailand and Argentina complements the results of other scholars. Their findings revealed that public deficit have an inverse effect on private investment in all the countries mentioned. However, the effect is stronger in Thailand but weak in Ivory Coast for Argentina, the study also found that deficit financing have a strong depressing outcome. And that public expenditure or consumption in the above countries crowds out private investment.

Other studies include Cebula (1987), who investigated the relationship between federal deficits and real rate of interest in the United States using instrumental variables. The findings revealed that budget deficits cause interest rates to rise, and this leads to crowding out of private investment.

Moreover, Karras (1994) studied the effects of budget deficits on money growth, inflation, investment, and real output growth. The study concludes that deficits do not lead to inflation through monetary expansion. Deficits are negatively correlated with the rate of growth of real output also increased deficits appeared to retard investment usually after one or two years.

Furthermore, Bahmani (1999) investigated the long-run relationship between U.S. federal real budget deficits and real fixed investment using quarterly data over the 1947-199 periods. The empirical results indicated that real budget deficits have crowded in real investment. The result supports the Keynesian school who argue for the expansionary effects of budget deficits, by raising the level of domestic economic activity, "crowd- in" private investment. The study by Moshi and Kilindo (1999), investigated the impacts of government policy on macroeconomic variables particularly on private investment in Tanzania. The results obtained lead to the conclusions that public expenditure especially on infrastructure exerts a positive and significant effect on private investment. Furthermore, foreign exchange availability positively affects private investment.

The study by Knot and de Haan (1999) in Germany and Modeste (2000) in Jamaica, on the relationship between budget deficit and interest rate, both studies supports their positive relationship. Despite the distinct methods that were employed in their study and the economic levels of the respective countries. The major implication of these studies is that budget deficits, to the extent that they force up interest rates, can cause "crowding out" of private investment.

Lastly, the study by Biza, R. A et al. (2013), investigated whether budget deficits crowd out or crowd in private investment in South Africa, using quarterly data covering the period 1994 to 2009. An empirical model linking private investment to its theoretical variables is specified and used to assess the quantitative effects of budget deficits on private investment. Results suggest that budget deficits significantly crowds out private investment. These results corroborate the theoretical predictions and are also supported by previous studies.

The literature discussed above shows that the relationship between budget deficits and investment is ambiguous. However, the writings have indicated a number of significant variables that are essential to investigate the relationship between budget deficits and private investment in the Tanzanian economy. It is obvious that economic indicators such as budget deficit, interest rates, change in real gross domestic product and inflation are relevant to investigate to explain their impact on the Tanzanian economy.

\section{Methodology}

The study seeks to analyze whether the budget deficit has detrimental effects on private investment. The method used is the application of the regression analysis to evaluate the relationship between deficit financing and private sector investment.

\section{Model Specification}

The study has adopted a model developed by Blanchard and Perotti (2002) with slight modification on independent variables. For analytical convenience, some variables are expressed either in ratio or percentage. The model is specified as follows:

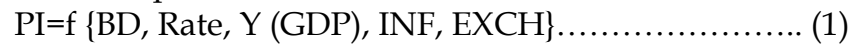
Where: PI is private investment, BD is budget deficits, Rate is interest rates, $\mathrm{Y}(\mathrm{GDP})$ is the growth rate of GDP, $\mathrm{EXCH}$ is exchange rate, and INFL is inflation. For analytical convenience, the variables are all expressed natural logarithm form. It takes the following function form, equation (1) becomes:

$P I_{t}=\beta_{0}+\beta_{1} B D_{t}+\beta_{2}$ Rate $_{t}+\beta_{3} Y(G D P)_{t}+\beta_{4} I N F_{t}+$

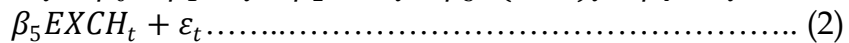
$\beta_{o}$ is the constant term, " $\mathrm{t}$ " is the time trend, and " $\varepsilon$ " is the random error term.

Budget deficits resulting from public investment can act as a substitute (negative result on private investment) to or a complement (positive result on) for private investment. The anticipated sign on budget deficits is not clear; it can either be positive or negative because it is dependent on the area in which the government executes the investment projects. 


\section{Data Sources}

The study employs secondary data from various institutions; the data collected include; private investment, inflation, budget deficit, exchange rate, interest rate and changes in GDP growth rates. The data collected ranges from the year 1970 to 2012; the study does not involve sampling since it involves the use of secondary data. Data are collected from Ministry of Finance and Economic Affairs of Tanzania, Economic survey of various years published by National Bureau of Statistics (NBS), World Economic Outlook database and Bank of Tanzania Economic Bulletins and various reports. The analysis involves the following stages:

\section{Unit Root Test}

Unit root test involves testing the order of integration of the individual series under consideration. Several procedures for the test of the order of integration have been developed. The most accepted ones are Augmented Dickey-Fuller (ADF) test of 1981 and the Phillips and Perron (1988). Augmented Dickey-Fuller test relies on rejecting a null hypothesis of the unit root (the series are non-stationary) in favor of the alternative hypotheses of stationarity. The Augmented Dickey-Fuller (ADF) Test takes the following formulation; with a drift and trend model specification representation;

$\Delta P_{t}=\alpha_{o}+\gamma P_{t-1}+\alpha_{2} t+\sum_{i=1}^{n} \beta_{i} \Delta P_{t-1}+\varepsilon_{t}$

Where, $\alpha_{o}$ is drift component, and $\alpha_{2} t$ is trend component. $\beta_{i}$ Is a measure of lag length and $\gamma$ is a measure of unit root

The Phillips and Perron test takes the following formulation;

$\Delta P_{t}=\alpha_{o}+\alpha_{t} P_{t-1}+\varepsilon_{t}$

\section{Cointegration Test}

Cointegration test involves testing of the presence or otherwise of cointegration between the series of the same order of integration through forming a cointegration equation. The basic idea behind cointegration is that if, in the long-run, two or more series move closely together, even though the sequence themselves are trended, the difference between them is constant. The absence of cointegration suggests that such variables have no long-run relationship: in principal they can wander arbitrarily far away from each other (Dickey et. al., 1991). We employ the maximum likelihood test procedure established by Johansen and Juselius (1990) and Johansen (1991).

To determine the number of co-integrating vectors, Johansen $(1988,1989)$ and Johansen and Juselius (1990) suggested two statistic tests, the first one is the trace test (trace). It tests the null hypothesis that the number of the distinct co-integrating vector is less than or equal to $\mathrm{q}$ against a general unrestricted alternatives $\mathrm{q}=\mathrm{r}$.

The Second statistical test is the Maximum Eigen value test; the test concerns a test of the null hypothesis that there is $r$ of co-integrating vectors against the alternative that $r+1$ co-integrating vector.

\section{The Error Correction Model}

If cointegration is proven to exist, then the next step requires the construction of error correction mechanism to dynamic model relationship. The purpose of the error correction model is to indicate the speed of adjustment from the short-run equilibrium to the long-run equilibrium state. The greater the coefficient of the parameter, the higher the speed of adjustment of the model from the short-run to the long-run and the opposite is correct.

With an error correction form that allows for inclusion of long-run information thus, the error correction model $(\mathrm{ECM})$ is formulated as follows;

$\Delta P_{t}=$

$\alpha_{o}+\sum_{i=1}^{n} \alpha_{1 i} \Delta R_{t-i}+\sum_{i=1}^{n} \alpha_{2 i} \Delta b d_{t-i}+$

$\sum_{i=1}^{n} \alpha_{3 i} \Delta Y(G D P)_{t-i}+\sum_{i=1}^{n} \alpha_{4 i} \Delta I n f_{t-i}+$

$\sum_{i=1}^{n} \alpha_{5 i} \Delta E x C h_{t-1}+\theta_{i} \hat{\varepsilon}_{t-1}+$

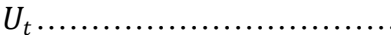

$\Delta$ is the difference operator

$\theta_{i}$ is called the adjustment parameters, measures the speed of how fast the equation will go back to the equilibrium, and usually take the negative value ($\left.1<\theta_{i} \leq 0\right)$. It is negative since disequilibrium declines overtime. $\varepsilon_{t}$ is a white noise error term, and $\hat{\varepsilon}_{t-1}$ is the lagged value of the error term. A significant coefficient implies that past equilibrium errors play a role in determining the current outcomes.

\section{ESTIMATION AND INTERPRETATION OF RESULTS}

\section{Unit Root Test}

The result in Table 1 shows that all the variables were not stationary in their levels. The presence of unit root has been traced by comparing the observed values (in absolute terms) of both the ADF and PP test statistics with the critical values (also in absolute terms) of the test statistics at the $1 \%, 5 \%$ and $10 \%$ level of significance. Result from the table provides strong evidence of nonstationarity. Therefore, it is sufficient to conclude that there is a presence of unit root in the variables at levels following results in Table 1.

Table 1: Presents Unit root test results

Critical values at levels are; -3.634 at $1 \%,-2.952$ at $5 \%$ and -2.610 at $10 \%$. Critical values at first difference are; -3.641 at $1 \%,-2.955$ at $5 \%$ and -2.611 at $10 \%$. The bracket indicates their respective probabilities.

\begin{tabular}{|c|c|c|c|c|}
\hline \multirow{2}{*}{ Variables } & \multicolumn{2}{|c|}{ At Levels } & \multicolumn{2}{c|}{ At First Difference } \\
\cline { 2 - 5 } & ADF & PP & ADF & PP \\
\hline BD & $-0.051(0.9541)$ & $0.754(0.9909)$ & $-6.361(0.0000)$ & $-6.585(0.0000)$ \\
\hline Rate & $-1.450(0.5583)$ & $-1.659(0.4522)$ & $-3.738(0.0036)$ & $-3.637(0.0051)$ \\
\hline INFL. & $-2.287(0.1763)$ & $-2.201(0.2060)$ & $-8.277(0.0000)$ & $-8.413(0.0000)$ \\
\hline EXCH & $2.389(0.9990)$ & $2.800(1.0000)$ & $-6.247(0.0000)$ & $-6.300(0.0000)$ \\
\hline$(\mathrm{Y})$ GDP & $-2.896(0.0458)$ & $-2.763(0.0637)$ & $-8.857(0.0000)$ & $-10.465(0.0000)$ \\
\hline PRIV & $0.481(0.9843)$ & $1.562(0.9977)$ & $-9.425(0.0000)$ & $-9.928(0.0000)$ \\
\hline
\end{tabular}

All the variables have been differenced once, and both the ADF and PP test were conducted on them, the result as shown in Table 1 . The results indicated that all variables are 
stationary. The results confirmed therefore that differencing once was all that was required to bring these variables to stationarity at all levels of significance. These results suggests that our variables are integrated of order one I(1). Mallik and Choudhry (2001) and Ahmed and Mortaza (2005) point out that the PP test can properly distinguish between stationary and non-stationary time series with the high degree of autocorrelation and presence of structural break.

\section{Cointegration Rank Test}

To have confirmed the stationarity of the variables at $I(1)$, we proceed to examine the presence or absence of cointegration among the variables. The presence of a cointegration relationship implies that variables in the model share a common trend and long-run equilibrium as suggested theoretically.

Table 2: Presents Johansen test results for cointegration

\begin{tabular}{|l|l|l|l|l|}
\hline \multicolumn{6}{|l|}{ Unrestricted Cointegration Rank Test (Trace) } \\
\hline $\begin{array}{l}\text { Hypothesized } \\
\text { No. of CE(s) }\end{array}$ & $\begin{array}{l}\text { Eigen } \\
\text { value }\end{array}$ & $\begin{array}{l}\text { Trace } \\
\text { Statistic }\end{array}$ & $\begin{array}{l}0.05 \\
\text { Critical } \\
\text { Value }\end{array}$ & Prob. $^{* *}$ \\
\hline None * & 0.668908 & 134.5456 & 107.3466 & 0.0003 \\
\hline At most 1 * & 0.610767 & 89.22588 & 79.34145 & 0.0074 \\
\hline At most 2 & 0.434182 & 50.53924 & 55.24578 & 0.1219 \\
\hline At most 3 & 0.326297 & 27.19047 & 35.01090 & 0.2668 \\
\hline At most 4 & 0.157366 & 10.99685 & 18.39771 & 0.3894 \\
\hline At most 5 * & 0.092438 & 3.976740 & 3.841466 & 0.0461 \\
\hline $\begin{array}{l}\text { Max-Eigen value test indicates 2 cointegratingeqn(s) at the 0.05 level } \\
\text { * denotes rejection of the hypothesis at the 0.05 level } \\
\text { **MacKinnon-Haug-Michelis (1999) p-values }\end{array}$ \\
\hline
\end{tabular}

\begin{tabular}{|c|c|c|c|c|}
\hline \multicolumn{5}{|c|}{ Unrestricted Cointegration Rank Test (Maximum Eigen value) } \\
\hline $\begin{array}{l}\text { Hypothesized } \\
\text { No. of CE(s) }\end{array}$ & $\begin{array}{l}\text { Eigen } \\
\text { value }\end{array}$ & $\begin{array}{l}\text { Max-Eigen } \\
\text { Statistic }\end{array}$ & $\begin{array}{l}0.05 \\
\text { Critical } \\
\text { Value } \\
\end{array}$ & Prob. $^{* *}$ \\
\hline None * & 0.668908 & 45.31973 & 43.41977 & 0.0307 \\
\hline At most 1 * & 0.610767 & 38.68664 & 37.16359 & 0.0332 \\
\hline At most 2 & 0.434182 & 23.34877 & 30.81507 & 0.3082 \\
\hline At most 3 & 0.326297 & 16.19362 & 24.25202 & 0.3978 \\
\hline At most 4 & 0.157366 & 7.020110 & 17.14769 & 0.7108 \\
\hline At most 5 * & 0.092438 & 3.976740 & 3.841466 & 0.0461 \\
\hline $\begin{array}{l}\text { Max-Eigen valu } \\
{ }^{*} \text { denotes reject } \\
* * \text { MacKinnon- }\end{array}$ & $\begin{array}{l}\text { test indica } \\
n \text { of the hy } \\
\text { ug-Michel }\end{array}$ & $\begin{array}{l}\text { s 2 cointegrat } \\
\text { thesis at the } \\
\text { (1999) p-valu }\end{array}$ & $\begin{array}{l}\text { geqn(s) at } \\
05 \text { level }\end{array}$ & e 0.05 leve \\
\hline
\end{tabular}

Table 2 shows that trace statistic indicate (1) cointegration and maximum Eigen value statistic indicates (2) cointegration at the 5 percent level of significance. These results suggests that there is cointegrating (long-run) relations between the variables so tested.

\section{Error Correction Results Analysis}

The error correction term appears with a statistically significant coefficient with the appropriate negative sign as required for dynamic stability. The results accord well with the validity of an equilibrium relationship among the variables in the cointegrating equation. The error correction term (ECT-1) has expected a negative sign and significant at 1 percent level of significance. Its magnitude reports the speed for adjustment of around 48.4 percent, which is relatively high. The result implies that, about
48.4 percent of the deviations from the long-run equilibrium are corrected in one period (Table 3 ).

Table 3: Presents Error Correction Mechanism results

\begin{tabular}{|c|c|c|c|c|}
\hline \multicolumn{5}{|c|}{$\begin{array}{l}\text { Included variable: } \\
\text { Dependent variable: Priv. }\end{array}$} \\
\hline Variable & Coefficient & $\begin{array}{l}\text { Standard } \\
\text { error }\end{array}$ & t-statistic & Probability \\
\hline $\operatorname{ECT}(-1)$ & -.4820095 & .1334514 & -3.61 & 0.001 \\
\hline$\Delta \mathrm{Bd}(-1)$ & -.0305764 & .1723458 & -0.18 & 0.860 \\
\hline$\Delta$ Rate $(-1)$ & .026107 & .0707759 & 0.37 & 0.715 \\
\hline$\Delta(\mathrm{Y}) \mathrm{GDP}(-1)$ & .11537 & .1270694 & 0.91 & 0.370 \\
\hline$\Delta$ Infl.(-1) & .0030376 & .0368624 & 0.08 & 0.935 \\
\hline$\Delta \operatorname{Exch}(-1)$ & -.003173 & .0041706 & -0.76 & 0.452 \\
\hline Constant & .5906276 & .285389 & 2.07 & 0.046 \\
\hline
\end{tabular}

Source: Own computation

\section{VECTOR ERROR CORRECTION ESTIMATES RESULTS}

Cointegration equation

Priv $=4.061067-0.0991 \mathrm{Bd}-0.3070$ Rate $+0.0171 \mathrm{Exch}+0.1289$ Infl $+0.372437 \mathrm{Y}(\mathrm{GDP})$ $\begin{array}{lllll}(0.01735) & (0.08717) & (0.00063) & (0.01504) & (0.05326) \\ {[5.71271]} & {[3.52135]} & {[-27.3070]} & {[-8.57285]} & {[-6.99263]}\end{array}$

The significance of error correction term substantiates the presence of cointegration between the dependent variable and the explanatory variables. The mechanism drives the variables to their long-run equilibrium relationship (Verbeek, 2008). The application of error correction mechanism drives the short-run dynamics of the series. The mechanism generates a force that pulls the equilibrium error back towards zero; the error correction model does this exactly.

\section{Vector Error Correction Analysis}

The vector error correction (VEC) model is just a special case of the VAR for variables that are stationary in their differences (i.e. I(1)). The VEC also takes into account any cointegrating relationships among the variables. The VEC specification restricts the long-run behavior of the endogenous variables to converge to their cointegrating relationship while allowing a broad range of short-run dynamics (Wooldridge, 2000).

Table 4 Presents Vector Error Correction Estimates

\begin{tabular}{|l|c|c|c|c|c|c|}
\hline $\begin{array}{l}\text { Error } \\
\text { Correction }\end{array}$ & D(PRIV) & $\mathbf{D}$ (BD) & $\mathbf{D}$ (RATE) & $\mathbf{D}$ (EXCH) & $\mathbf{D}$ (INFL) & D(YGDP) \\
\hline CointEq1 & -0.095936 & -0.680579 & -0.659367 & -24.26980 & 1.508397 & 0.187418 \\
& $(0.25688)$ & $(0.10864)$ & $(0.76834)$ & $(10.1784)$ & $(1.88060)$ & $(0.41491)$ \\
\hline D(PRIV(-1)) & -0.676789 & 0.795103 & 0.484535 & 16.80945 & -0.592676 & -0.238765 \\
& $(0.20186)$ & $(0.08537)$ & $(0.60377)$ & $(7.99832)$ & $(1.47780)$ & $(0.32604)$ \\
\hline D(PRIV(-2)) & -0.728899 & 0.869142 & 0.317560 & 28.89649 & -0.854203 & -0.079832 \\
& $(0.21006)$ & $(0.08884)$ & $(0.62832)$ & $(8.32355)$ & $(1.53789)$ & $(0.33930)$ \\
\hline D(PRIV(-3)) & -0.509982 & 0.753337 & -0.173835 & -1.432342 & -1.464055 & 0.114160 \\
& $(0.20124)$ & $(0.08511)$ & $(0.60192)$ & $(7.97381)$ & $(1.47327)$ & $(0.32504)$ \\
\hline D(BD(-1)) & 0.103774 & -0.142347 & -0.158737 & 1.430532 & 0.657244 & -0.15298 \\
& $(0.23957)$ & $(0.10132)$ & $(0.71658)$ & $(9.49268)$ & $(1.75390)$ & $(0.38696)$ \\
\hline D(BD(-2)) & -0.607494 & -0.243263 & 0.531165 & 1.445456 & 1.015098 & -0.301705 \\
& $(0.17177)$ & $(0.07265)$ & $(0.51380)$ & $(6.80637)$ & $(1.25757)$ & $(0.27745)$ \\
\hline D(BD(-3)) & 0.186025 & -0.242075 & -0.331733 & -17.86533 & 1.226065 & -0.076592 \\
& $(0.26334)$ & $(0.11138)$ & $(0.78769)$ & $(10.4348)$ & $(1.92796)$ & $(0.42536)$ \\
\hline D(RATE(-1)) & 0.054478 & 0.022103 & 0.554100 & -0.162462 & 0.137625 & 0.227744 \\
& $(0.07915)$ & $(0.03347)$ & $(0.23673)$ & $(3.13605)$ & $(0.57943)$ & $(0.12784)$ \\
\hline D(RATE(-2)) & -0.137883 & -0.002565 & -0.118311 & 5.004398 & -0.271299 & -0.299505 \\
& $(0.09531)$ & $(0.04031)$ & $(0.28507)$ & $(3.77645)$ & $(0.69775)$ & $(0.15394)$ \\
\hline D(RATE(-3)) & 0.037892 & 0.037577 & -0.226449 & -3.166942 & 0.256895 & 0.185822 \\
& $(0.07411)$ & $(0.03135)$ & $(0.22168)$ & $(2.93668)$ & $(0.54259)$ & $(0.11971)$ \\
\hline D(EXCH(-1)) & 0.020320 & -0.010265 & -0.007358 & -0.592328 & 0.059472 & 0.002575 \\
& $(0.00890)$ & $(0.00377)$ & $(0.02663)$ & $(0.35275)$ & $(0.06518)$ & $(0.01438)$ \\
\hline
\end{tabular}




\begin{tabular}{|c|c|c|c|c|c|c|}
\hline $\mathrm{D}(\mathrm{EXCH}(-2))$ & $\begin{array}{r}0.006232 \\
(0.00620) \\
\end{array}$ & $\begin{array}{r}-0.012592 \\
(0.00262) \\
\end{array}$ & $\begin{array}{l}-0.008864 \\
(0.01854) \\
\end{array}$ & $\begin{array}{r}0.021639 \\
(0.24558) \\
\end{array}$ & $\begin{array}{c}-0.010312 \\
(0.04537) \\
\end{array}$ & $\begin{array}{r}0.012953 \\
(0.01001) \\
\end{array}$ \\
\hline $\mathrm{D}(\mathrm{EXCH}(-3))$ & $\begin{array}{l}0.016881 \\
(0.00566)\end{array}$ & $\begin{array}{r}-0.014437 \\
(0.00240)\end{array}$ & $\begin{array}{r}-0.031922 \\
(0.01694)\end{array}$ & $\begin{array}{c}-0.269792 \\
(0.22441)\end{array}$ & $\begin{array}{r}-0.014228 \\
(0.04146)\end{array}$ & $\begin{array}{l}0.010156 \\
(0.00915)\end{array}$ \\
\hline D(INFL(-1)) & $\begin{array}{r}0.005443 \\
(0.03820)\end{array}$ & $\begin{array}{r}-0.036616 \\
(0.01616)\end{array}$ & $\begin{array}{l}-0.001975 \\
(0.11426)\end{array}$ & $\begin{array}{l}-4.069083 \\
(1.51369)\end{array}$ & $\begin{array}{l}-0.240407 \\
(0.27968)\end{array}$ & $\begin{array}{r}0.090377 \\
(0.06170)\end{array}$ \\
\hline D(INFL(-2)) & $\begin{array}{r}0.004031 \\
(0.03861) \\
\end{array}$ & $\begin{array}{r}-0.013309 \\
(0.01633) \\
\end{array}$ & $\begin{array}{l}-0.067411 \\
(0.11549) \\
\end{array}$ & $\begin{array}{l}-2.953962 \\
(1.52995) \\
\end{array}$ & $\begin{array}{l}-0.020753 \\
(0.28268) \\
\end{array}$ & $\begin{array}{l}-0.024775 \\
(0.06237) \\
\end{array}$ \\
\hline D(INFL(-3)) & $\begin{array}{r}0.028051 \\
(0.03736)\end{array}$ & $\begin{array}{r}-0.013664 \\
(0.01580) \\
\end{array}$ & $\begin{array}{r}0.010746 \\
(0.11175) \\
\end{array}$ & $\begin{array}{l}-1.869389 \\
(1.48040)\end{array}$ & $\begin{array}{r}0.090583 \\
(0.27352) \\
\end{array}$ & $\begin{array}{l}0.064183 \\
(0.06035) \\
\end{array}$ \\
\hline$\overline{D(Y G D P(-1))}$ & $\begin{array}{r}0.016708 \\
(0.18201) \\
\end{array}$ & $\begin{array}{l}-0.341414 \\
(0.07698) \\
\end{array}$ & $\begin{array}{l}-0.257894 \\
(0.54440)\end{array}$ & $\begin{array}{l}-11.29102 \\
(7.21183) \\
\end{array}$ & $\begin{array}{l}0.120595 \\
(1.33248) \\
\end{array}$ & $\begin{array}{l}-0.10526 \\
(0.29398) \\
\end{array}$ \\
\hline $\mathrm{D}($ YGDP(-2)) & $\begin{array}{r}-0.029491 \\
(0.14563) \\
\end{array}$ & $\begin{array}{r}-0.20732 \\
(0.06159) \\
\end{array}$ & $\begin{array}{l}-0.338049 \\
(0.43559) \\
\end{array}$ & $\begin{array}{l}-6.917529 \\
(5.77031) \\
\end{array}$ & $\begin{array}{l}-0.195835 \\
(1.06614) \\
\end{array}$ & $\begin{array}{l}-0.402173 \\
(0.23522) \\
\end{array}$ \\
\hline D(YGDP(-3)) & $\begin{array}{r}0.024816 \\
(0.13223) \\
\end{array}$ & $\begin{array}{r}-0.207221 \\
(0.05592) \\
\end{array}$ & $\begin{array}{c}-0.136238 \\
(0.39550) \\
\end{array}$ & $\begin{array}{r}-3.690237 \\
(5.23933) \\
\end{array}$ & $\begin{array}{c}-0.621233 \\
(0.96804)\end{array}$ & $\begin{array}{r}0.007776 \\
(0.21357) \\
\end{array}$ \\
\hline $\mathrm{C}$ & \begin{tabular}{|c|}
-0.101078 \\
$(0.41657)$ \\
\end{tabular} & $\begin{array}{l}0.698109 \\
(0.17618) \\
\end{array}$ & $\begin{array}{l}1.532434 \\
(1.24600) \\
\end{array}$ & $\begin{array}{l}55.54750 \\
(16.5060) \\
\end{array}$ & $\begin{array}{r}-0.790252 \\
(3.04971) \\
\end{array}$ & $\begin{array}{r}-0.598405 \\
(0.67284) \\
\end{array}$ \\
\hline R-squared & 0.781113 & 0.947675 & 0.560625 & 0.714176 & 0.339670 & 0.534533 \\
\hline $\begin{array}{ll}\begin{array}{l}\text { Adj. } \\
\text { squared }\end{array} & R \\
\end{array}$ & 0.562227 & 0.895351 & 0.121250 & 0.428352 & -0.320661 & 0.069067 \\
\hline S.E. equation & 1.091394 & 0.461586 & 3.264480 & 43.24532 & 7.990161 & 1.762838 \\
\hline F-statistic & 3.568575 & 18.11149 & 1.275959 & 2.498658 & 0.514394 & 1.148381 \\
\hline Akaike AIC & 3.319306 & 1.598223 & 5.510596 & 10.67817 & 7.300817 & 4.278245 \\
\hline Schwarz SC & 4.172415 & 2.451332 & 6.363705 & 11.53128 & 8.153926 & 5.131353 \\
\hline \multicolumn{3}{|c|}{ Akaike information criterion } & \multicolumn{4}{|l|}{31.30197} \\
\hline
\end{tabular}

Standard error is in ( ). Source: Own computations

Table 4 shows that equation one is significant at 5 percent and coefficient of Error Correction Term (ECT) is negative as required, indicating the existence of dynamic stability. Negative and statistically significant values of the coefficients of the error correction terms indicate the existence of long-run causality.

\section{Conclusion And Recommendations}

The study investigated whether budget deficits crowd out private investments in the Tanzanian economy in the period 1970 to 2012. All the variables have a long-run relationship with private investment. An increase in the budget deficit and interest lending rate negatively impact private investments in the long run. On contrary other variables such as GDP growth rates, inflation rates and exchange rates positively impacts on private investment as estimated from cointegration equation and ordinary least square.

These results imply that if an economy continuously experiences fiscal deficits, private investment deteriorates, thus being crowded out. It follows from these findings that private investment is largely a function of both real and nominal variables in the long run. These results, therefore, for the most part, agree with part of both the theoretical predictions and findings from previous research that assert fiscal deficits caused by public consumption crowds out private investment.

The result entails that the monetary authorities have the ability to influence the changes in private investment. The authorities may, however, reduce the impact of this shock, in the long run, by utilizing stringent monetary policies to promote private investment and acting on other fundamentals. More generally, coordination of monetary and fiscal policies will be imperative for efficient policy response to the crowding out effect as rising interest rates may also add to spending pressures. However, GDP growth rates and exchange rates contribute to strong economic performance whereby government policies should be redirected in their favor. Serven and Solimano (1991) arrived at the same results that supported the importance of changes in output in determining private investment.

Mobilizing domestic savings and creating conditions that stimulate greater levels of local, private investments are consequently critical ingredients for success especially in many of the poorest countries. Indeed, increased levels of domestic private investment should contribute to attracting more foreign investment as well. However, enhancing private investment should not focus on attracting foreign direct investment (FDI) alone. While FDI to developing countries has increased significantly in the last 20 years, the bulk of investment is domestic (World Bank, 2004)

\section{REFERENCES}

Ahmed, S and G. Mortaza (2005) Inflation and Economic Growth in Bangladesh: 1981- 2005. Policy Analysis Unit (PAU) Working Paper 0604

Biza, R.A et al. (2013) "Do Budget Deficits Crowd Out Private Investment? An Analysis of the South African Economy."

Blanchard, O and R. Perotti (2002) "An Empirical characterization of the Dynamic effects of Changes in

Government Spending and Taxes on Output" Quarterly Journal of Economics, November 2002, Vol.117, No.4, Pages 1329 -1368.

Blejer, M.I. and M.S. Khan (2010), 'Government Policy and Private Investment in Developing Countries', IMF Staff Papers

Cebula, R.J. (1987) "Federal deficits and real rate of interest in the United States," Public Choice 58: 1: 97-100.

Cochrane, J.H (2005), "Time series for macroeconomics and finance", Graduate school of Business research paper, University of Chicago.

Cooksey, B. (2011) Public goods, rents and business in Tanzania, UK Aid and Irish Aid, Background Paper 01, June 2011.

Darrat, A.F. (1989), “Fiscal Deficits and the Long-Term Interest Rates: Further Evidence from Annual Data" Southern Economic Journal, Vol. 56(2): 363-374.

Easterly, W and S. Rebelo (1993), "Fiscal policy and economic growth: An empirical investigation." Journal of Monetary Economics, 32: 417-458.

Ewing, B. T. and M.A.Yanochik(1999), "Budget Deficits and the Term Structure of Interest Rates in Italy", Applied Economics Letters, Vol. 6, pp. 1999-201.

Greene, J and D. Villanueva (1991), "Private Investment in Developing Countries: An Empirical Analysis" IMF Staff Papers, Vol. 38, No. 1

Humpage, O. F. (1992), An Introduction to the International Implications of U.S. Fiscal Policy", Economic Review (Federal Reserve Bank of Cleveland), Vol. 28, No. 3, pp. 27-39.

Johansen, S. and K. Juselius (1990), "Maximum likelihood estimation and inference on cointegration; applications to the demand for money", Oxford Bulletin of Economic and Statistics, Vol. 52, pp. 169-210.

Khan, S. and M. Arshad (2001), 'What determines Private Investment', A case of Pakistan, the Pakistan Institute of Development Economics, working paper no.36.

Kilindo, A.A.L (1997), "Fiscal Operation, Money Supply and Inflation in Tanzania" AERC Research Paper, University of Dar es Salaam. 
Knot, K. and J. de Haan(1999), "Deficit Announcement and Interest Rates: Evidence for Germany", Journal of Policy Modeling", Vol. 21, No. 5, pp. 559-77.

Mallik, G. and A. Chowdhury (2001), Inflation and Economic Growth: Evidence from South Asian Countries, "Asian Pacific Development Journal, Vol. 8, No.1 pp. 123-135.

Modeste, N. C. (2000), “The Impact of Budget Deficits on LongTerm Interest Rates in Jamaica, 1964-1996: An Application of the Error Correction Methodology", International Review of Economics and Business, Vol. 47, No. 4, pp. 667-78.

Moshi, H. P. B and A. A. Kilindo (1999) "The Impact of government policy on macroeconomic variables: A case study of private investment in Tanzania, AERC Research Paper 89, Nairobi.

Report for the OECD Project Emerging Africa, OECD Development Representation, Estimation, and Testing", Econometrica, Vol. 55, Retrieved March 18, 2013
Serven, L. and A. Solimano (1992), "Private investment and macroeconomic adjustment: A survey". The World Bank Research Observer, vol. 7, no. 1:95-114.

Sims, C (1980), "Macroeconomics and reality," Econometrica, 48, 148.

Sims, C. (1982), "Policy analysis with econometric models," Brookings paper on economic activity, 1, 107-52

UNCTAD (2002) Investment Policy Review of Tanzania.

Verbeek, M. (2008) A Guide To Modern Econometrics, 3 ${ }^{\text {rded, }}$ John Wiley and Sons Ltd, England

World Bank Group (2004), Improving investment climate: an evaluation of World Bank Group assistance, IBRD/IDA Operations Evaluation Department, IFC Operations Evaluation Group, and MIGA Operations Evaluation Unit, Washington DC. 